\title{
PENGARUH PENJUALAN TERHADAP CURRENT RATIO, QUICK RATIO DAN CASH RATIO PADA PT. CAHAYA PRIMA SENTOSA
}

\author{
Taufan Alam Saputro ${ }^{1}$, Rawidjo ${ }^{2}$ \\ ${ }^{1}$ STIE Muhammadiyah Jakarta, taufan@stiemj.ac.id \\ ${ }^{1}$ STIE Muhammadiyah Jakarta, rawidjo@stiemj.ac.id
}

\begin{abstract}
ABSTRAK
Tujuan dari penelitian ini adalah untuk mengetahui adakah pengaruh penjualan terhadap current ratio, quick ratio dan cash ratio likuiditas perusahaan pada PT. Cahaya Prima Sentosa. Jenis data dalam penelitian ini adalah data sekunder yang merupakan data kuantitatif yang berupa angka nominal dari perusahaan yang diteliti yaitu berupa laporan keungan PT. Cahaya Prima Sentosa tahun 2012-2016. Pengujian hipotesis dalam penelitian ini menggunakan regresi linear sederhana dengan uji $\mathrm{t}$ dan uji F. Berdasarkan hasil penelitian yang telah dilakukan: Bahwa volume penjualan berpengaruh kuat terhadap Current Ratio, yang artiya penjualan berpengaruh kuat terhadap Current Ratio, Uji hipotesis dengan menggunakan analisis korelasi diperoleh hasil bahwa volume penjualan berpengaruh kuat terhadap likuiditas dan Uji hipotesis dengan menggunakan analisis korelasi diperoleh hasil bahwa penjualan berpengaruh kuat terhadap likuiditas.
\end{abstract}

Kata Kunci : Penjualan, Current Ratio, Quick Ratio Dan Cash Ratio.

\section{ABSTRACT}

The purpose of this study is to determine whether there is an effect of sales on the current ratio, quick ratio and cash ratio of the company's liquidity at PT. Cahaya Prima Sentosa. The type of data in this study is secondary data which is quantitative data in the form of nominal figures from the company studied in the form of financial reports of PT. Cahaya Prima Sentosa 20122016. Testing the hypothesis in this study using simple linear regression with $t$ test and $F$ test. Based on the results of research that has been done: That sales volume has a strong effect on Current Ratio, which means that sales have a strong effect on Current Ratio, Hypothesis testing using correlation analysis shows that sales volume has a strong effect on liquidity and Hypothesis testing using correlation analysis results show that sales have a strong effect on liquidity.

Keywords: Sales, Current Ratio, Quick Ratio and Cash Ratio.

\section{PENDAHULUAN}

Membuka kesempatan kerja serta meningkatkan pendapatan adalah keinginan banyak masyarakat pada zaman modern ini. Tujuan yang ingin dicapai dengan didirikannya perusahaan itu pada umumnya untuk mencapai laba yang optimal, mempertahankan kelangsungan hidup perusahaan yang ingin tumbuh, berkembang dan berkesinambungan. Dalam rangka mencapai tujuan tersebut, faktor utama yang harus diperhatikan adalah adanya cara memaksimalkan laba dan hal ini dapat dilakukan dengan aktivitas penjualan. Dari penjualan inilah, perusahaan memperoleh keuntungan yang akan dipergunakan untuk melangsungkan dan mengembangkan kegiatan operasional perusahaan.

Faktor umum yang paling penting menentukan kelangsungan hidup suatu perusahaan adalah penjualan, tanpa adanya penjualan yang cukup maka perusahaan tersebut 
tidak akan mencapai tujuan utamanya. Penjualan terdiri dari penjualan tunai dan penjualan kredit. Penjualan tunai merupakan penjualan yang transaksinya dilakukan secara tunai, perusahan lebih dimudahkan dalam penjualan tunai ini karena perusahaan akan segera menerima kas. Sedangkan penjualan kredit lebih banyak dipilih oleh para pembeli karena pembayaran untuk pembelian barang dapat ditunda, selain pembeli perusahaan juga mendapat keuntungan dari adanya penjualan kredit ini karena perusahaan akan mendapatkan pendapatan lebih besar dibandingkan dengan penjualan secara tunai.

Semakin berkembangnya dunia usaha saat ini berarti bertambah pula keinginan berbagai perusahaan untuk mengembangkan usaha dengan tujuan utamanya agar perusahaan menjadi kekuatan utama (Market Leader) dan mendapatkan laba yang maksimal sesuai dengan jumlah modal yang dimiliki oleh perusahaan tersebut. Pendapatan merupakan hal yang penting bagi kelangsungan hidup perusahaan. Tanpa adanya pendapatan, perusahaan tidak akan mampu membiayai pengeluaran-pengeluaran untuk kegiatan operasinya. Demikian pentingnya pendapatan ini, maka perusahaan dituntut untuk menyelenggarakan perlakuan yang tepat terhadap besar kecilnya pendapatan yang diperoleh.

Dalam perusahaan besar maupun kecil, laporan keuangan mempunyai peranan yang sangat penting sebagai alat bantu bagi manajemen untuk mengetahui posisi atau keadaan keuangan dalam memenuhi segala kewajibannya. Laporan keuangan bukan berarti menunjukkan perkembangan perusahaan saja, tetapi lebih berguna apabila di analisis untuk dapat mengetahui perkembangan keuangan yang telah dicapai di waktu yang lalu maupun waktu yang sedang berjalan.

Dengan menganalisis data keuangan dari tahun lalu, dapat di ketahui kelemahankelemahan maupun kelebihan-kelebihan yang ada di dalam perusahaan serta hasil-hasil yang telah dicapai.

Karakteristik dunia usaha saat ini ditandai oleh perkembangan yang cepat di segala bidang. Perusahaan akan melakukan berbagai aktivitas untuk mencapai tujuannya yaitu memperoleh keuntungan, menjaga kelangsungan hidup, dan pertumbuhan. Oleh sebab itu pihak manajemen selain dituntut untuk mengkoordinasikan penggunaan seluruh sumber daya yang dimiliki perusahaan secara efektif dan efisien, juga dituntut untuk dapat menghasilkan keputusan-keputusan yang menunjang terhadap pencapaian tujuan perusahaan.

Tujuan perusahaan secara umum adalah mendapatkan laba. Satu aktivitas utama perusahaan dalam pencapaian laba adalah penjualan. Perusahaan yang kami teliti bergerak di bidang percetakan, penerbitan dan penjilidan buku.

Mengacu pada beberapa penelitian terdahulu yaitu Bongsu Saragih (2012) dalam penelitiannya menghasilkan kebijakan penjualan mempunyai pengaruh positif terhadap likuiditas, sedangkan menurut dan Luthfy Dwi Aldiansyah (2013) menyimpulkan bahwa penjualan tidak berpengaruh terhadap likuiditas dan Siti Marhamah (2015) menyimpulkan bahwa penjualan berpengaruh kuat terhadap likuiditas.

Berdasarkan uraian di atas maka penulis bertujuan untuk menganalisis pengaruh penjualan terhadap current ratio, quick ratio dan cash ratio pada pt. Cahaya prima sentosa.

\section{KAJIAN LITERATUR Penjualan}

Penjualan merupakan suatu transaksi yang dilakukan oleh dua belah pihak atau lebih dengan menggunakan alat pembayaran yang sah, dengan penjualan juga merupakan salah satu sumber pendapatan seseorang atau perusahaan yang melakukan transaksi jual dan beli, dalam suatu perusahaan apabila semakin besar penjualan maka akan semakin besar pula pendapatan yang diperoleh. Penjualan menurut Thamrin Abdullah dan Francis Tantri (2016:3), "Penjualan adalah bagian dari promosi dan promosi adalah salah satu bagian dari keseluruhan sistem pemasaran". 


\section{Pengertian Likuiditas}

Masalah likuiditas berhubungan dengan masalah kemampuan perusahaan untuk memenuhi kewajiban keuangannya yang segera harus dipenuhi. Perusahaan yang mampu memenuhi segala kewajiban keuangan jangka pendeknya tepat waktu digolongkan sebagai perusahaan yang likuid. Menurut Sartono (2008:116), mengemukakan bahwa : "Likuiditas perusahaan menunjukan kemampuan untuk membayar kewajiban finansial jangka pendek tepat pada waktunya". Didalam rasio likuiditas terdapat beberapa cara untuk menganalisa dan mengetahui posisi keuangan jangka pendek (likuiditas) dengan beberapa rasio yang dapat digunakan seperti :

\section{Current Ratio}

Current ratio merupakan perbandingan antara aktiva lancar dan kewajiban lancar dan merupakan ukuran yang paling umum digunakan untuk mengetahui kesanggupan suatu perusahaan memenuhi kewajiban jangka pendeknya. Apabila mengukur tingkat likuiditas dengan menggunakan current ratio sebagai alat pengukurnya, maka tingkat likuiditas atau current ratio suatu perusahaan dapat dipertinggi dengan cara Dengan utang lancar tertentu, diusahakan untuk menambah aktiva lancar. Dengan aktiva lancar tertentu, diusahakan untuk mengurangi jumlah utang lancar. Dengan mengurangi jumlah utang lancar sama-sama dengan mengurangi aktiva lancar.

$$
\text { Rasio Lancar }=\frac{\text { Aktiva Lancar }}{\text { Hutang Lancar }} \times 100 \%
$$

\section{Quick Ratio}

Menurut Kasmir (2012:136) "Rasio cepat (quick ratio) atau rasio sangat lancar atau acid test ratio merupakan rasio yang menunjukkan kemampuan perusahaan dalam memenuhi atau membayar kewajiban atau utang lancar (utang jangk pendek) dengan aktiva lancar tanpa memperhitungkan nilai sediaan (inventory). Artinya mengabaikan nilai sediaan, dengan cara dikurangi dari total aktiva lancar. Hal ini dilakukan karena sediaan dianggap memerlukan waktu relatif lebih lama untuk diuangkan, apabila perusahaan membutuhkan dana cepat untuk membayar kewajibannya dibandingkan dengan aktiva lancar lainnya.".

$$
\text { Quick Ratio }=\frac{\text { Aktiva Lancar - Persediaan }}{\text { Hutang Lancar }} \times 100 \%
$$

Rasio ini merupakan ukuran kemampuan perusahaan dalam memenuhi kewajiban kewajibannya dengan tidak memperhitungkan persediaan, karena persediaan memerlukan waktu yang relatif lama untuk direalisir menjadi uang kas, dan menganggap bahwa piutang segera dapat direalisir menjadi uang kas, walaupun kenyataannya persediaan lebih likuid daripada piutang.

\section{Cash ratio}

Rasio ini merupakan rasio yang menunjukkan posisi kas yang dapat menutupi hutang lancar dengan kata lain cash ratio merupakan rasio yang menggambarkan kemampuan kas yang dimiliki. 


$$
\text { Cash Ratio }=\frac{\text { Cash }+ \text { Efek }}{\text { Hutang Lancar }} \times 100 \%
$$

Bertambah tinggi Cash Ratio berarti jumlah uang tunai yang tersedia makin besar sehingga pelunasan utang pada saat jatuh tempo tidak akan mengalami kesulitan. Tetapi bila terlalu tinggi akan mengurangi potensi untuk mempertinggi Rate Of Return.

\section{Kerangka Pikir}

Berikut uraian dari kerangka pikir diatas, dapat digambarkan sebagai berikut :

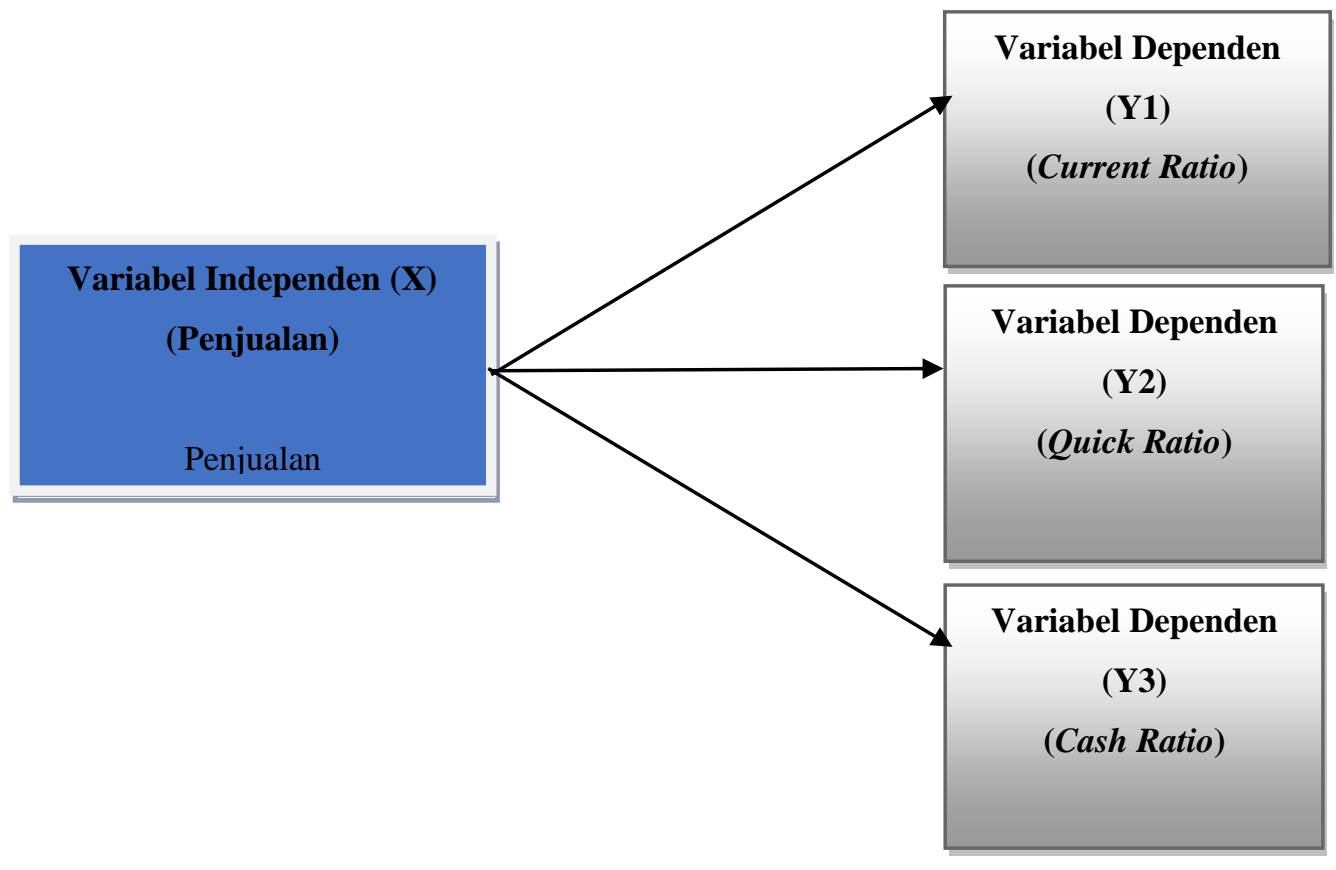

Hipotesis merupakan suatu jawaban atau dugaan sementara terhadap suatu masalah yang harus teruji kebenararannya atas suatu penelitian berdasarkan data yang telah dikumpulkan.

Adapun rangkaian hipotesa yang dikembangkan oleh penulis adalah :

a. Ho : $\beta=0$, tidak terdapat pengaruh yang signifikan antara penjualan terhadap likuiditas PT. CAHAYA PRIMA SENTOSA.

b. Ha : $\beta \neq 0$, terdapat pengaruh yang signifikan antara penjualan terhadap likuiditas PT. CAHAYA PRIMA SENTOSA.

\section{METODE PENELITIAN}

\section{Operasionalisasi Variabel Penelitian}

\begin{tabular}{|l|l|l|l|l|}
\hline Variable & Konsep Variabel & Indikator & Ukuran & Skala \\
\hline (Variabel & Penjualan merupakan & HPP . Rp & Rasio \\
Independen X) & kegiatan yang & Persediaan awal & & \\
Penjualan & dilakukan oleh & barang dagangan & & \\
Bersih & penjual dalam & + pembelian & & \\
& menjual barang atau & bersih r - & & \\
\hline
\end{tabular}




\begin{tabular}{|c|c|c|c|c|}
\hline & 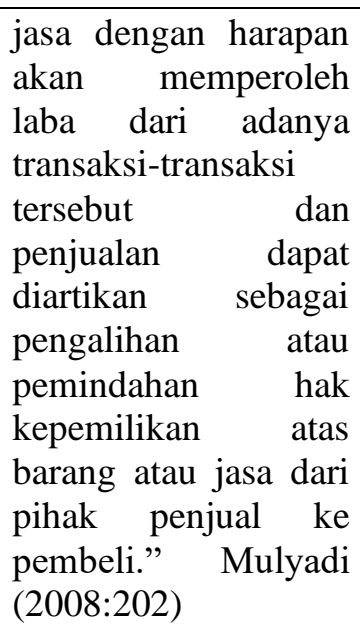 & persediaan akhir & & \\
\hline $\begin{array}{l}\text { (Variabel } \\
\text { Dependent Y1, } \\
\text { Y2, dan Y3) } \\
\text { Current } \\
\text { Quatio, } \\
\text { Quick Ratio } \\
\text { dan Cash } \\
\text { Ratio } \\
\text { Likuiditas }\end{array}$ & $\begin{array}{l}\text { "mengukur } \\
\text { kemampuan } \\
\text { perusahaan untuk } \\
\text { melunasi kewajiban } \\
\text { (utang) jangka } \\
\text { pendek tepat pada } \\
\text { waktunya, termasuk } \\
\text { melunasi bagian } \\
\text { utang jangka panjang } \\
\text { yang jatuh tempo } \\
\text { pada } \\
\text { bersangkutan." } \\
\text { Mardiyanto ( } 2009 \text { : } \\
54 \text { ) }\end{array}$ & $\begin{array}{l}\text { Cash Ratio = } \\
\text { Cash + Efek X } \\
100 \% \\
\text { Hutang Lancar }\end{array}$ & $\mathrm{Rp}$ & Rasio \\
\hline
\end{tabular}

\section{PEMBAHASAN}

\section{Uji Deskripsi variabel independen}

Berdasarkan data yang telah di peroleh maka dapat di jelaskan bahwa Penjualan periode 2012-2016 mempunyai rata-rata 1,6666663, penjualan minimum sebesar 0,99237 per bulan yang terjadi pada bulan Januari 2012, penjualan maksimum sebesar 2,40967 pada bulan Desember 2016.

Uraian diatas mengenai Penjulalan tahun 2012-2016 dapat dilihat pada tabel berikut:

TABEL 4.3

Descriptive Statistics

\begin{tabular}{|l|l|l|l|l|l|}
\hline & $\mathrm{N}$ & Minimum & Maximum & Mean & Std. Deviation \\
\hline $\begin{array}{l}\text { Penjualan } \\
\begin{array}{l}\text { Valid } \\
\text { (listwise) }\end{array}\end{array}$ & 60 & .9923685 & 2.4096664 & 1.666666 & .3452924427 \\
\hline
\end{tabular}

Sumber Output SPSS 


\section{Uji Deskripsi Variabel Dependen}

TABEL 4.4

Descriptive Statistics

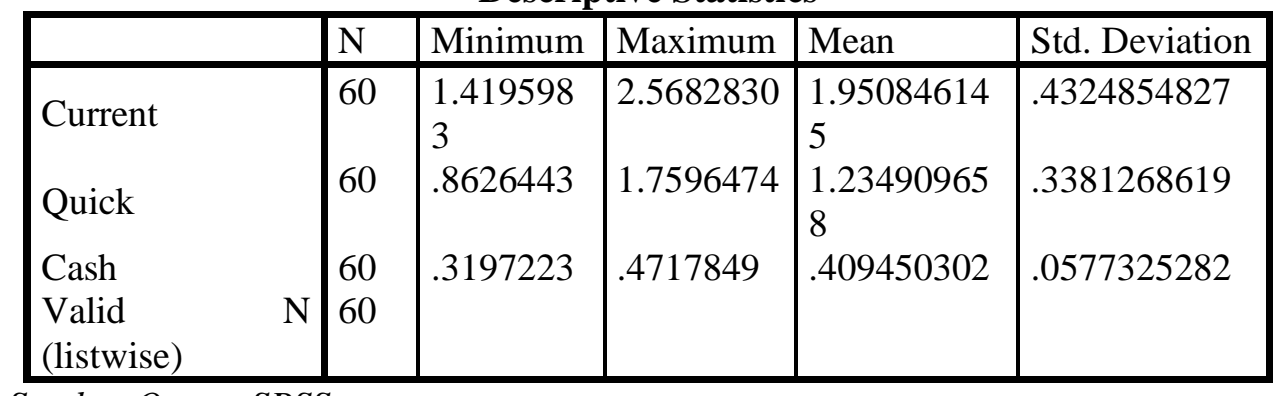

Sumber Output SPSS

Berdasarkan data yang di peroleh maka nilai masing-masing variable bebas dapat di jelaskan sebagai berikut :

\section{Current Ratio}

Berdasarkan data yang di peroleh pada tahun 2012-2016 maka rata - rata Current Ratio sebesar 1,950846145 persen, sedangkan Current Ratio terendah sebesar 1,4195983 persen yang terjadi pada bulan Juli 2012 dan Current Ratio tertinggi sebesar 2,5682830 persen yang terjadi pada bulan September 2015.

2. Quick Ratio

Berdasarkan data yang di peroleh pada tahun 2012-2016 maka rata - rata Quick Ratio sebesar 1,234909658, sedangkan Quick Ratio terendah sebesar 0,8626443 persen yang terjadi pada bulan Januari 2013 dan Quick Ratio tertinggi sebesar 1,7596474 persen yang terjadi pada bulan September 2015.

3. Cash Ratio

Berdasarkan data yang di peroleh pada tahun 2012-2016 maka rata - rata Cash Ratio sebesar 0,409450302, sedangkan Cash Ratio terendah sebesar 0,3197223 persen yang terjadi pada bulan Juli 2012 dan Cash Ratio tertinggi sebesar 0,4717849 persen yang terjadi pada bulan Juni 2016.

\section{Pembahasan \\ Analisis Ratio Keuangan}

Analisis rasio keuangan adalah alat analisis keuangan perusahaan untuk menilai kinerja suatu perusahaan berdasarkan perbandingan data keuangan yang terdapat pada pos laporan keuangan (neraca, laporan laba/rugi, laporan aliran kas). Meskipun didasarkan pada data dan kondisi masa lalu, analisis rasio keuangan dimaksudkan untuk menilai risiko dan peluang pada masa yang akan datang. Pengukuran dan hubungan satu pos dengan pos lain dalam laporan keuangan yang tampak dalam rasio-rasio keuangan dapat memberikan kesimpulan yang berarti dalam penentuan tingkat kesehatan keuangan suatu perusahaan. Rasio menggambarkan suatu hubungan atau perimbangan antara suatu jumlah tertentu dengan jumlah yang lainnya, dan dengan menggunakan alat analisis berupa rasio ini akan dapat menjelaskan atau memberi gambaran kepada penganalisa tentang baik atau buruknya keadaan atau posisi keuangan suatu perusahaan terutama apabila angka rasio tersebut dibandingkan dengan angka rasio pembanding yang digunakan sebagai standar, salah satunya dengan menggunakan analisis rasio likuiditas.

Analisis rasio likuiditas adalah rasio yang mengukur kemampuan jangka pendek perusahaan dengan melihat aktiva lancar perusahaan relatif terhadap hutang lancarnya (hutang dalam hal ini merupakan kewajiban perusahaan).

\section{Rasio Lancar / Curent Rasio}


Rasio Lancar merupakan salah satu rasio likuiditas yang berfungsi untuk mengukur kemampuan perusahaan dalam membiayai utang lancar atau kewajiban jangka pendek. Rasio lancar mengukur ketersediaannya aset lancar yang dapat segera diuangkan untuk membayar uang lancar perusahaan. Semakin besar rasio ini, maka semakin baik kondisi keuangan suatu perusahaan Untuk menghitung rasio ini menggunakan rumus sebagai berikut :

Rumus :

Rasio Lancar $=\frac{\text { Aktiva Lancar }}{\text { Hutang Lancar }} \times 100 \%$

TABEL 4.5

Current Ratio

PT. CAHAYA PRIMA SENTOSA

Pada tahun 2012-2016

\begin{tabular}{|l|l|l|l|l|}
\hline No & Periode & Aktiva Lancar & Hutang Lancar & Ratio \\
\hline 1 & Jan-12 & $2,691,315,480$ & $1,895,790,510$ & 1,4196270 \\
\hline 2 & Feb-12 & $2,862,634,433$ & $2,016,476,709$ & 1,4196219 \\
\hline 3 & Mar-12 & $3,038,699,617$ & $2,140,530,576$ & 1,4196011 \\
\hline 4 & Apr-12 & $3,219,333,942$ & $2,267,745,927$ & 1,4196184 \\
\hline 5 & May-12 & $3,407,058,098$ & $2,399,978,415$ & 1,4196203 \\
\hline 6 & Jun-12 & $3,599,351,395$ & $2,535,372,386$ & 1,4196539 \\
\hline 7 & Jul-12 & $3,794,342,472$ & $2,672,828,195$ & 1,4195983 \\
\hline 8 & Aug-12 & $3,995,951,141$ & $2,814,751,317$ & 1,4196462 \\
\hline 9 & Sep-12 & $4,204,767,701$ & $2,961,829,032$ & 1,4196524 \\
\hline 10 & Oct-12 & $4,420,792,152$ & $3,114,061,340$ & 1,4196227 \\
\hline 11 & Nov-12 & $4,643,729,346$ & $3,271,104,601$ & 1,4196212 \\
\hline 12 & Dec-12 & $4,878,384,540$ & $3,436,395,210$ & 1,4196227 \\
\hline 13 & Jan-13 & $4,145,914,547$ & $2,744,063,029$ & 1,5108671 \\
\hline No & Periode & Aktiva Lancar & Hutang Lancar & Ratio \\
\hline 14 & Feb-13 & $4,309,520,282$ & $2,852,344,927$ & 1,5108693 \\
\hline 15 & Mar-13 & $4,477,611,900$ & $2,963,597,975$ & 1,5108702 \\
\hline 16 & Apr-13 & $4,650,189,404$ & $3,077,822,173$ & 1,5108701 \\
\hline 17 & May-13 & $4,829,495,735$ & $3,196,503,095$ & 1,5108685 \\
\hline 18 & Jun-13 & $5,013,271,818$ & $3,318,134,533$ & 1,5108706 \\
\hline
\end{tabular}


JURNAL AKUNTANSI, Vol. 8, No. 1, April (2019)

\begin{tabular}{|c|c|c|c|c|}
\hline 19 & Jul-13 & $5,199,290,844$ & $3,441,251,547$ & 1,5108721 \\
\hline 20 & Aug-13 & $5,392,054,829$ & $3,568,845,918$ & 1,5108679 \\
\hline 21 & Sep-13 & $5,591,515,377$ & $3,700,855,747$ & 1,5108709 \\
\hline 22 & Oct-13 & $5,797,704,751$ & $3,837,322,301$ & 1,5108725 \\
\hline 23 & Nov-13 & $6,010,622,953$ & $3,978,245,579$ & 1,5108728 \\
\hline 24 & Dec-13 & $6,234,755,867$ & $4,126,596,732$ & 1,5108711 \\
\hline 25 & Jan-14 & $6,772,689,439$ & $3,174,578,294$ & 2,1334139 \\
\hline 26 & Feb-14 & $6,935,895,984$ & $3,251,084,659$ & 2,1334098 \\
\hline 27 & Mar-14 & $7,103,550,113$ & $3,329,666,618$ & 2,1334118 \\
\hline 28 & Apr-14 & $7,766,095,773$ & $3,637,892,209$ & 2,1347790 \\
\hline 29 & May-14 & $7,454,521,552$ & $3,494,178,136$ & 2,1334120 \\
\hline 30 & Jun-14 & $7,637,838,862$ & $3,580,107,694$ & 2,1334104 \\
\hline 31 & Jul-14 & $7,823,476,606$ & $3,667,158,073$ & 2,1333895 \\
\hline 32 & Aug-14 & $8,015,689,081$ & $3,757,238,818$ & 2,1333989 \\
\hline 33 & Sep-14 & $8,214,621,251$ & $3,850,474,465$ & 2,1334049 \\
\hline 34 & Oct-14 & $8,420,273,116$ & $3,946,865,013$ & 2,1334079 \\
\hline 35 & Nov-14 & $8,632,644,677$ & $4,046,410,463$ & 2,1334081 \\
\hline 36 & Dec-14 & $8,856,183,515$ & $4,151,186,408$ & 2,1334102 \\
\hline 37 & Jan-15 & $7,843,781,882$ & $3,054,100,373$ & 2,5682790 \\
\hline 38 & Feb-15 & $8,012,180,875$ & $3,119,700,460$ & 2,5682533 \\
\hline 39 & Mar-15 & $8,185,041,555$ & $3,186,973,621$ & 2,5682803 \\
\hline 40 & Apr-15 & $8,362,602,008$ & $3,256,114,401$ & 2,5682765 \\
\hline No & Periode & Aktiva Lancar & Hutang Lancar & Ratio \\
\hline 41 & May-15 & $8,547,164,504$ & $3,328,017,699$ & 2,5682449 \\
\hline 42 & Jun-15 & $8,736,188,688$ & $3,401,594,072$ & 2,5682631 \\
\hline 43 & Jul-15 & $8,927,562,758$ & $3,476,104,254$ & 2,5682667 \\
\hline 44 & Aug-15 & $9,125,891,254$ & $3,553,338,045$ & 2,5682587 \\
\hline 45 & Sep-15 & $9,331,031,324$ & $3,633,178,721$ & 2,5682830 \\
\hline 46 & Oct-15 & $9,543,173,437$ & $3,715,781,914$ & 2,5682814 \\
\hline
\end{tabular}


JURNAL AKUNTANSI, Vol. 8, No. 1, April (2019)

\begin{tabular}{|l|l|l|l|l|}
\hline 47 & Nov-15 & $9,762,222,358$ & $3,801,069,809$ & 2,5682828 \\
\hline 48 & Dec-15 & $9,992,830,244$ & $3,890,871,115$ & 2,5682758 \\
\hline 49 & Jan-16 & $9,501,833,985$ & $4,477,925,331$ & 2,1219277 \\
\hline 50 & Feb-16 & $9,714,194,650$ & $4,578,061,432$ & 2,1219013 \\
\hline 51 & Mar-16 & $9,932,123,702$ & $4,680,672,162$ & 2,1219439 \\
\hline 52 & Apr-16 & $10,155,995,345$ & $4,786,160,366$ & 2,1219505 \\
\hline 53 & May-16 & $10,388,567,045$ & $4,895,734,583$ & 2,1219629 \\
\hline 54 & Jun-16 & $10,626,867,504$ & $5,007,956,076$ & 2,1219969 \\
\hline 55 & Jul-16 & $10,868,406,547$ & $5,121,904,054$ & 2,1219465 \\
\hline 56 & Aug-16 & $11,118,592,188$ & $5,239,880,495$ & 2,1219171 \\
\hline 57 & Sep-16 & $11,377,424,427$ & $5,361,885,401$ & 2,1219074 \\
\hline 58 & Oct-16 & $11,644,689,433$ & $5,487,688,572$ & 2,1219662 \\
\hline 59 & Nov-16 & $11,921,028,699$ & $5,617,980,604$ & 2,1219419 \\
\hline 60 & Dec-16 & $12,211,743,322$ & $5,754,948,375$ & 2,1219553 \\
\hline
\end{tabular}

Sumber Laporan Keuangan PT. CAHAYA PRIMA SENTOSA

Gambar 4.2

Grafik Current Ratio

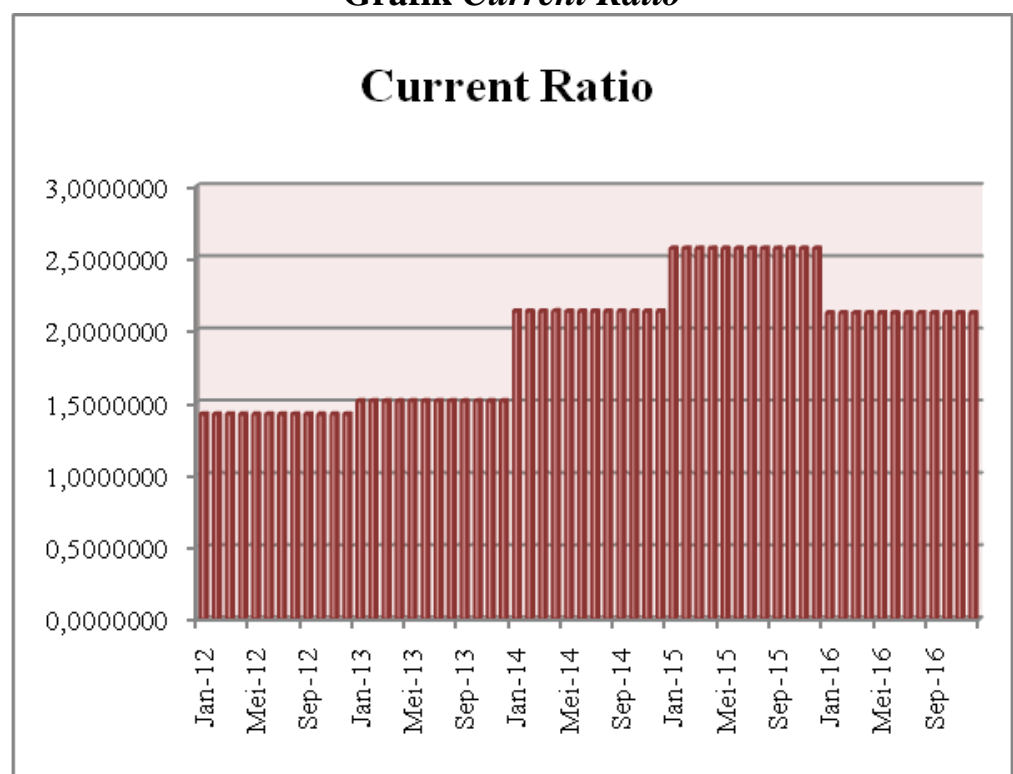

Berdasarkan dari tabel dan grafik di atas dapat disimpulkan bahwa nilai rasio pada Current Ratio mengalami kenaikan pada tahun 2013-2015. Hal ini disebabkan karena adanya peningkatan aktiva lancar lebih besar dibandingkan peningkatan hutang lancar lancar. Sedangkan pada tahun 2016 biarpun aktiva lancar mengalami kenaikan tetapi hutang lancar 
juga mengalami peningkatan yang besar sehingga pada tahun 2016 mengalami penurunan current rasio.

\section{Rasio Cepat/Quick Rasio}

Merupakan rasio yang digunakan untuk mengukur kemampuan perusahaan dalam membayar kewajiban jangka pendeknya dengan menggunakan aktiva yang lebih likuid . Quick Ratio dapat dihitung dengan rumus yaitu :

$$
\text { Quick Ratio }=\frac{\text { Aktiva Lancar }- \text { Persediaan }}{\text { Hutang Lancar }} \times 100 \%
$$

TABEL 4.6

Quick Ratio

PT. CAHAYA PRIMA SENTOSA

Pada tahun 2012-2016

\begin{tabular}{|l|l|l|l|l|l|}
\hline No & Periode & Aktiva Lancar & Persediaan & $\begin{array}{l}\text { Hutang } \\
\text { Lancar }\end{array}$ & Ratio \\
\hline 1 & Jan-12 & $2,691,315,480$ & $1,020,705,427$ & $1,895,790,510$ & 0,8812208 \\
\hline 2 & Feb-12 & $2,862,634,433$ & $1,085,683,629$ & $2,016,476,709$ & 0,8812156 \\
\hline 3 & Mar-12 & $3,038,699,617$ & $1,152,475,004$ & $2,140,530,576$ & 0,8811949 \\
\hline 4 & Apr-12 & $3,219,333,942$ & $1,220,968,542$ & $2,267,745,927$ & 0,8812122 \\
\hline 5 & May-12 & $3,407,058,098$ & $1,292,163,338$ & $2,399,978,415$ & 0,8812141 \\
\hline 6 & Jun-12 & $3,599,351,395$ & $1,365,060,296$ & $2,535,372,386$ & 0,8812477 \\
\hline 7 & Jul-12 & $3,794,342,472$ & $1,439,067,360$ & $2,672,828,195$ & 0,8811921 \\
\hline 8 & Aug-12 & $3,995,951,141$ & $1,515,479,653$ & $2,814,751,317$ & 0,8812400 \\
\hline 9 & Sep-12 & $4,204,767,701$ & $1,594,667,212$ & $2,961,829,032$ & 0,8812462 \\
\hline 10 & Oct-12 & $4,420,792,152$ & $1,676,630,035$ & $3,114,061,340$ & 0,8812165 \\
\hline 11 & Nov-12 & $4,643,729,346$ & $1,761,183,106$ & $3,271,104,601$ & 0,8812149 \\
\hline 12 & Dec-12 & $4,878,384,540$ & $1,850,176,600$ & $3,436,395,210$ & 0,8812164 \\
\hline 13 & Jan-13 & $4,145,914,547$ & $1,778,764,242$ & $2,744,063,029$ & 0,8626443 \\
\hline 14 & Feb-13 & $4,309,520,282$ & $1,848,955,038$ & $2,852,344,927$ & 0,8626465 \\
\hline 15 & Mar-13 & $4,477,611,900$ & $1,921,071,801$ & $2,963,597,975$ & 0,8626474 \\
\hline 16 & Apr-13 & $4,650,189,404$ & $1,995,114,531$ & $3,077,822,173$ & 0,8626473 \\
\hline 17 & May-13 & $4,829,495,735$ & $2,072,046,212$ & $3,196,503,095$ & 0,8626457 \\
\hline 18 & Jun-13 & $5,013,271,818$ & $2,150,890,484$ & $3,318,134,533$ & 0,8626478 \\
\hline & & & & & \\
\hline
\end{tabular}


JURNAL AKUNTANSI, Vol. 8, No. 1, April (2019)

\begin{tabular}{|c|c|c|c|c|c|}
\hline 19 & Jul-13 & $5,199,290,844$ & $2,230,697,740$ & $3,441,251,547$ & 0,8626493 \\
\hline 20 & Aug-13 & $5,392,054,829$ & $2,313,407,322$ & $3,568,845,918$ & 0,8626451 \\
\hline 21 & Sep-13 & $5,591,515,377$ & $2,398,979,104$ & $3,700,855,747$ & 0,8626481 \\
\hline 22 & Oct-13 & $5,797,704,751$ & $2,487,439,837$ & $3,837,322,301$ & 0,8626497 \\
\hline 23 & Nov-13 & $6,010,622,953$ & $2,578,789,520$ & $3,978,245,579$ & 0,8626500 \\
\hline No & Periode & Aktiva Lancar & Persediaan & $\begin{array}{l}\text { Hutang } \\
\text { Lancar }\end{array}$ & Ratio \\
\hline 24 & Dec-13 & $6,234,755,867$ & $2,674,954,121$ & $4,126,596,732$ & 0,8626483 \\
\hline 25 & Jan-14 & $6,772,689,439$ & $2,653,406,488$ & $3,174,578,294$ & 1,2975843 \\
\hline 26 & Feb-14 & $6,935,895,984$ & $2,717,352,772$ & $3,251,084,659$ & 1,2975802 \\
\hline 27 & Mar-14 & $7,103,550,113$ & $2,783,033,899$ & $3,329,666,618$ & 1,2975822 \\
\hline 28 & Apr-14 & $7,766,095,773$ & $3,040,657,970$ & $3,637,892,209$ & 1,2989494 \\
\hline 29 & May-14 & $7,454,521,552$ & $2,920,537,494$ & $3,494,178,136$ & 1,2975824 \\
\hline 30 & Jun-14 & $7,637,838,862$ & $2,992,359,962$ & $3,580,107,694$ & 1,2975808 \\
\hline 31 & Jul-14 & $7,823,476,606$ & $3,065,119,245$ & $3,667,158,073$ & 1,2975599 \\
\hline 32 & Aug-14 & $8,015,689,081$ & $3,140,411,398$ & $3,757,238,818$ & 1,2975693 \\
\hline 33 & Sep-14 & $8,214,621,251$ & $3,218,340,510$ & $3,850,474,465$ & 1,2975753 \\
\hline 34 & Oct-14 & $8,420,273,116$ & $3,298,906,583$ & $3,946,865,013$ & 1,2975783 \\
\hline 35 & Nov-14 & $8,632,644,677$ & $3,382,109,617$ & $4,046,410,463$ & 1,2975785 \\
\hline 36 & Dec-14 & $8,856,183,515$ & $3,469,684,452$ & $4,151,186,408$ & 1,2975806 \\
\hline 37 & Jan-15 & $7,843,781,882$ & $2,469,654,315$ & $3,054,100,373$ & 1,7596434 \\
\hline 38 & Feb-15 & $8,012,180,875$ & $2,522,700,881$ & $3,119,700,460$ & 1,7596177 \\
\hline 39 & Mar-15 & $8,185,041,555$ & $2,577,100,355$ & $3,186,973,621$ & 1,7596447 \\
\hline 40 & Apr-15 & $8,362,602,008$ & $2,633,010,051$ & $3,256,114,401$ & 1,7596409 \\
\hline 41 & May-15 & $8,547,164,504$ & $2,691,153,619$ & $3,328,017,699$ & 1,7596093 \\
\hline 42 & Jun-15 & $8,736,188,688$ & $2,750,650,094$ & $3,401,594,072$ & 1,7596275 \\
\hline 43 & Jul-15 & $8,927,562,758$ & $2,810,901,680$ & $3,476,104,254$ & 1,7596311 \\
\hline 44 & Aug-15 & $9,125,891,254$ & $2,873,355,674$ & $3,553,338,045$ & 1,7596231 \\
\hline 45 & Sep-15 & $9,331,031,324$ & $2,937,917,687$ & $3,633,178,721$ & 1,7596474 \\
\hline
\end{tabular}


JURNAL AKUNTANSI, Vol. 8, No. 1, April (2019)

\begin{tabular}{|l|l|l|l|l|l|}
\hline 46 & Oct-15 & $9,543,173,437$ & $3,004,713,571$ & $3,715,781,914$ & 1,7596458 \\
\hline 47 & Nov-15 & $9,762,222,358$ & $3,073,680,400$ & $3,801,069,809$ & 1,7596472 \\
\hline 48 & Dec-15 & $9,992,830,244$ & $3,146,296,933$ & $3,890,871,115$ & 1,7596402 \\
\hline 49 & Jan-16 & $9,501,833,985$ & $3,352,122,185$ & $4,477,925,331$ & 1,3733395 \\
\hline 50 & Feb-16 & $9,714,194,650$ & $3,427,082,892$ & $4,578,061,432$ & 1,3733131 \\
\hline No & Periode & Aktiva Lancar & Persediaan & $\begin{array}{l}\text { Hutang } \\
\text { Lancar }\end{array}$ & Ratio \\
\hline 51 & Mar-16 & $9,932,123,702$ & $3,503,896,076$ & $4,680,672,162$ & 1,3733557 \\
\hline 52 & Apr-16 & $10,155,995,345$ & $3,582,863,303$ & $4,786,160,366$ & 1,3733623 \\
\hline 53 & May-16 & $10,388,567,045$ & $3,664,889,272$ & $4,895,734,583$ & 1,3733747 \\
\hline 54 & Jun-16 & $10,626,867,504$ & $3,748,896,961$ & $5,007,956,076$ & 1,3734087 \\
\hline 55 & Jul-16 & $10,868,406,547$ & $3,834,197,076$ & $5,121,904,054$ & 1,3733583 \\
\hline 56 & Aug-16 & $11,118,592,188$ & $3,922,512,851$ & $5,239,880,495$ & 1,3733289 \\
\hline 57 & Sep-16 & $11,377,424,427$ & $4,013,844,287$ & $5,361,885,401$ & 1,3733192 \\
\hline 58 & Oct-16 & $11,644,689,433$ & $4,108,019,060$ & $5,487,688,572$ & 1,3733779 \\
\hline 59 & Nov-16 & $11,921,028,699$ & $4,205,554,141$ & $5,617,980,604$ & 1,3733537 \\
\hline 60 & Dec-16 & $12,211,743,322$ & $4,308,086,602$ & $5,754,948,375$ & 1,3733671 \\
\hline Sumber & & & \\
\hline
\end{tabular}

Sumber laporan Keuangan PT. CAHAYA PRIMA SENTOSA

Gambar 4.3

Grafik Quick Ratio

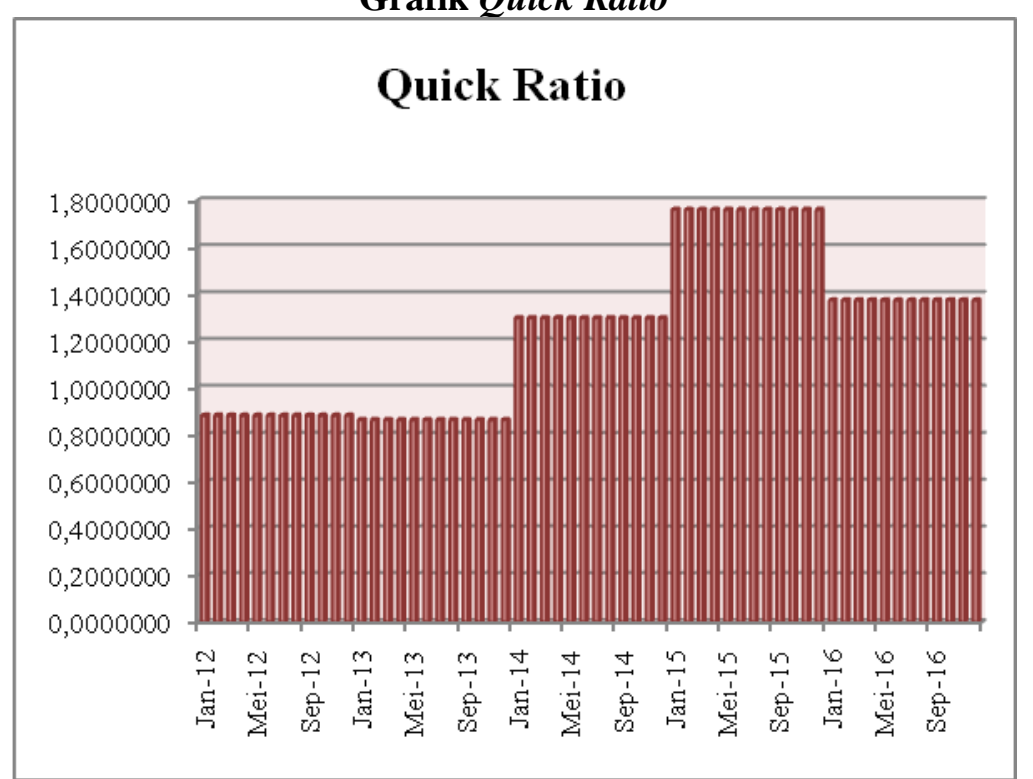


Berdasarkan dari tabel dan grafik di atas dapat disimpulkan bahwa nilai Quick Ratio sama hal nya seperti Current Ratio yang relatif mengalami peningkatan setiap tahunnya dan mengalami penurunan hanya pada tahun 2016. Kenaikan nilai ratio disebabkan karena peningkatan hutang lancar pada bulan-bulan di tahun 2013 lebih kecil dibandingkan peningkatan hasil aktiva lancar dikurangi persediaan. Hal ini serupa pada bulan-bulan di tahun 2014 dan 2015. Sedangkan pada bulan-bulan di tahun 2016 cenderung mengalami penurunan. Penurunan nilai rasio pada bulan-bulan di tahun 2016 ini disebabkan kenaikan hasil aktiva lancar dikurangi persediaan lebih sedikit dibandingkan kenaikan hutang lancar.

\section{Rasio Kas/Cash Ratio}

Rasio kas merupakan rasio yang menunjukkan kemampuan perusahaan dalam membayar kewajiban jangka pendek dengan menggunakan kas yang dimiliki oleh perusahaan. Tidak ada standar khusus besarnya cash ratio yang ditetapkan. Namun dari ketiga rasio likuiditas maka yang paling jarang di gunakan adalah rasio kas karena di anggap terlalu sempit.

Rumus :

Cash Ratio $=\frac{\text { Cash }+ \text { Efek }}{\text { Hutang Lancar }} \times 100 \%$

TABEL 4.7

Cash Ratio

PT. CAHAYA PRIMA SENTOSA

Pada tahun 2012-2016

\begin{tabular}{|l|l|l|l|l|}
\hline No & Periode & Kas Setara Kas & Hutang Lancar & Ratio \\
\hline 1 & Jan-12 & $606,180,906$ & $1,895,790,510$ & 0,3197510 \\
\hline 2 & Feb-12 & $644,759,998$ & $2,016,476,709$ & 0,3197458 \\
\hline 3 & Mar-12 & $684,381,305$ & $2,140,530,576$ & 0,3197251 \\
\hline 4 & Apr-12 & $725,094,513$ & $2,267,745,927$ & 0,3197424 \\
\hline 5 & May-12 & $767,379,323$ & $2,399,978,415$ & 0,3197443 \\
\hline 6 & Jun-12 & $810,756,034$ & $2,535,372,386$ & 0,3197779 \\
\hline 7 & Jul-12 & $854,562,760$ & $2,672,828,195$ & 0,3197223 \\
\hline 8 & Aug-12 & $900,073,586$ & $2,814,751,317$ & 0,3197702 \\
\hline 9 & Sep-12 & $947,122,890$ & $2,961,829,032$ & 0,3197764 \\
\hline 10 & Oct-12 & $995,710,672$ & $3,114,061,340$ & 0,3197466 \\
\hline 11 & Nov-12 & $1,045,919,744$ & $3,271,104,601$ & 0,3197451 \\
\hline 12 & Dec-12 & $1,098,775,756$ & $3,436,395,210$ & 0,3197466 \\
\hline
\end{tabular}


JURNAL AKUNTANSI, Vol. 8, No. 1, April (2019)

\begin{tabular}{|c|c|c|c|c|}
\hline 13 & Jan-13 & $1,014,618,381$ & $2,744,063,029$ & 0,3697504 \\
\hline 14 & Feb-13 & $1,054,661,832$ & $2,852,344,927$ & 0,3697526 \\
\hline 15 & Mar-13 & $1,095,800,739$ & $2,963,597,975$ & 0,3697535 \\
\hline 16 & Apr-13 & $1,138,035,103$ & $3,077,822,173$ & 0,3697534 \\
\hline 17 & May-13 & $1,181,912,651$ & $3,196,503,095$ & 0,3697518 \\
\hline 18 & Jun-13 & $1,226,893,068$ & $3,318,134,533$ & 0,3697539 \\
\hline 19 & Jul-13 & $1,272,421,213$ & $3,441,251,547$ & 0,3697554 \\
\hline 20 & Aug-13 & $1,319,585,129$ & $3,568,845,918$ & 0,3697512 \\
\hline 21 & Sep-13 & $1,368,407,055$ & $3,700,855,747$ & 0,3697542 \\
\hline 22 & Oct-13 & $1,418,872,165$ & $3,837,322,301$ & 0,3697558 \\
\hline 23 & Nov-13 & $1,470,980,460$ & $3,978,245,579$ & 0,3697561 \\
\hline No & Periode & Kas Setara Kas & Hutang Lancar & Ratio \\
\hline 24 & Dec-13 & $1,525,827,395$ & $4,126,596,732$ & 0,3697544 \\
\hline 25 & Jan-14 & $1,462,917,528$ & $3,174,578,294$ & 0,4608226 \\
\hline 26 & Feb-14 & $1,498,160,195$ & $3,251,084,659$ & 0,4608186 \\
\hline 27 & Mar-14 & $1,534,378,827$ & $3,329,666,618$ & 0,4608206 \\
\hline 28 & Apr-14 & $1,676,389,057$ & $3,637,892,209$ & 0,4608133 \\
\hline 29 & May-14 & $1,610,189,739$ & $3,494,178,136$ & 0,4608207 \\
\hline 30 & Jun-14 & $1,649,782,020$ & $3,580,107,694$ & 0,4608191 \\
\hline 31 & Jul-14 & $1,689,820,061$ & $3,667,158,073$ & 0,4607983 \\
\hline 32 & Aug-14 & $1,731,364,270$ & $3,757,238,818$ & 0,4608076 \\
\hline 33 & Sep-14 & $1,774,351,312$ & $3,850,474,465$ & 0,4608137 \\
\hline 34 & Oct-14 & $1,818,781,188$ & $3,946,865,013$ & 0,4608167 \\
\hline 35 & Nov-14 & $1,864,653,899$ & $4,046,410,463$ & 0,4608168 \\
\hline 36 & Dec-14 & $1,912,945,407$ & $4,151,186,408$ & 0,4608190 \\
\hline 37 & Jan-15 & $1,298,635,057$ & $3,054,100,373$ & 0,4252103 \\
\hline 38 & Feb-15 & $1,326,448,559$ & $3,119,700,460$ & 0,4251846 \\
\hline 39 & Mar-15 & $1,355,138,234$ & $3,186,973,621$ & 0,4252116 \\
\hline 40 & Apr-15 & $1,384,525,249$ & $3,256,114,401$ & 0,4252078 \\
\hline
\end{tabular}


JURNAL AKUNTANSI, Vol. 8, No. 1, April (2019)

\begin{tabular}{|c|c|c|c|c|}
\hline 41 & May-15 & $1,414,994,039$ & $3,328,017,699$ & 0,4251762 \\
\hline 42 & Jun-15 & $1,446,339,003$ & $3,401,594,072$ & 0,4251945 \\
\hline 43 & Jul-15 & $1,478,032,637$ & $3,476,104,254$ & 0,4251980 \\
\hline 44 & Aug-15 & $1,510,843,813$ & $3,553,338,045$ & 0,4251900 \\
\hline 45 & Sep-15 & $1,544,879,834$ & $3,633,178,721$ & 0,4252144 \\
\hline 46 & Oct-15 & $1,579,997,631$ & $3,715,781,914$ & 0,4252127 \\
\hline 47 & Nov-15 & $1,616,268,736$ & $3,801,069,809$ & 0,4252142 \\
\hline 48 & Dec-15 & $1,654,426,258$ & $3,890,871,115$ & 0,4252072 \\
\hline 49 & Jan-16 & $2,112,307,583$ & $4,477,925,331$ & 0,4717157 \\
\hline 50 & Feb-16 & $2,159,422,445$ & $4,578,061,432$ & 0,4716893 \\
\hline No & Periode & Kas Setara Kas & Hutang Lancar & Ratio \\
\hline 51 & Mar-16 & $2,208,022,034$ & $4,680,672,162$ & 0,4717318 \\
\hline 52 & Apr-16 & $2,257,815,771$ & $4,786,160,366$ & 0,4717384 \\
\hline 53 & May-16 & $2,309,566,776$ & $4,895,734,583$ & 0,4717508 \\
\hline 54 & Jun-16 & $2,362,677,972$ & $5,007,956,076$ & 0,4717849 \\
\hline 55 & Jul-16 & $2,416,178,687$ & $5,121,904,054$ & 0,4717345 \\
\hline 56 & Aug-16 & $2,471,678,181$ & $5,239,880,495$ & 0,4717051 \\
\hline 57 & Sep-16 & $2,529,176,454$ & $5,361,885,401$ & 0,4716954 \\
\hline 58 & Oct-16 & $2,588,839,548$ & $5,487,688,572$ & 0,4717541 \\
\hline 59 & Nov-16 & $2,650,169,333$ & $5,617,980,604$ & 0,4717299 \\
\hline 60 & Dec-16 & $2,714,858,087$ & $5,754,948,375$ & 0,4717433 \\
\hline
\end{tabular}

Sumber laporan Keuangan PT. CAHAYA PRIMA SENTOSA

Gambar 4.4

Grafik Cash Ratio 


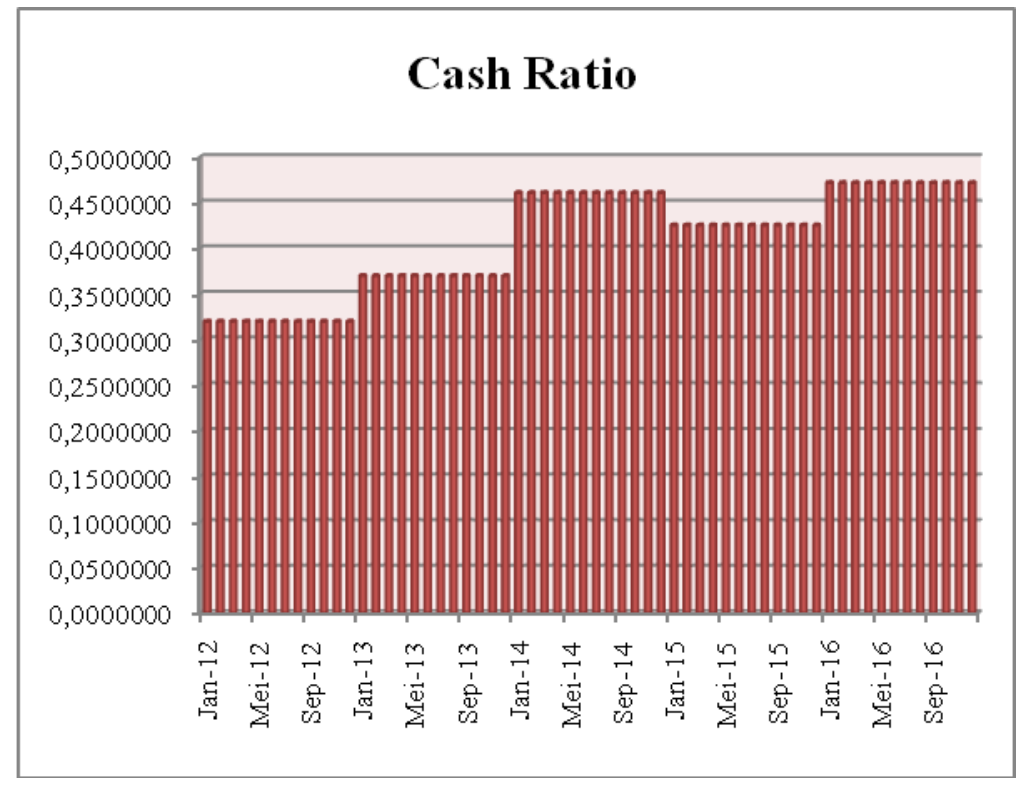

Berdasarkan dari tabel dan grafik di atas dapat di simpulkan bahwa nilai cash ratio pada bulan-bulan di tahun 2013-2014 cenderung mengalami peningkatan sedangkan pada bulan-bulan di tahun 2015 PT. CAHAYA PRIMA SENTOSA mengalami penurunan.

Peningkatan cash ratio pada bulan-bulan di tahun 2013-2014 disebabkan karena adanya kenaikan kas dan setara kas lebih besar dibandingkan dengan kenaikan hutang lancar.

Pada tahun 2015 mengalami penurunan yang menyebabkan perusahaan mengalami kesulitan dalam kegiatan perusahaan, salah satunya adalah dalam membayar utang jangka pendek yang dimiliki perusahaan.

\section{Current Ratio}

\section{Analisa Regresi linear sederhana atau Koefisien determinasi}

TABEL 4.8

Model Summary

\begin{tabular}{|l|l|l|l|l|}
\hline Model & $\mathrm{R}$ & $\mathrm{R}$ Square & $\begin{array}{l}\text { Adjusted R } \\
\text { Square }\end{array}$ & $\begin{array}{l}\text { Std. Error of the } \\
\text { Estimate }\end{array}$ \\
\hline 1 & $.726^{\mathrm{a}}$ & .527 & .519 & .2999846629 \\
\hline
\end{tabular}

a. Predictors: (Constant), Penjualan

Sumber Output SPSS

Dari tabel Model Summary diatas menunjukkan Angka R hitung sebesar 0,726 menunjukkan bahwa korelasi atau hubungan antara penjualan terhadap Likuditas kuat karena memiliki angka antara $0,60-0,799$.

Angka $\mathrm{R}$ Square $\left(\mathrm{R}^{2}\right)$ atau koefisien determinasi adalah 0,527 berasal dari $0,726 \mathrm{x}$ 0,726. Hal ini $\mathbf{R}$ square penjualan memiliki kontribusi terhadap likuditas sebesar 52,7\% sementara $47,3 \%$ di pengaruhi oleh factor-faktor lain.

\section{a. Uji F Statistik}

TABEL 4.9

ANOVA $^{\text {a }}$

\begin{tabular}{|l|ll|l|l|l|l|}
\hline Model & $\begin{array}{l}\text { Sum of } \\
\text { Squares }\end{array}$ & Df & Mean Square & F & Sig. \\
\hline
\end{tabular}




\begin{tabular}{|ll|l|l|l|l|l|}
\hline \multirow{2}{*}{1} & Regression & 5.816 & 1 & 5.816 & 64.630 & $.000^{\mathrm{b}}$ \\
& Residual & 5.219 & 58 & .090 & & \\
& Total & 11.036 & 59 & & & \\
\hline
\end{tabular}

a. Dependent Variable: Current

b. Predictors: (Constant), Penjualan

Sumber Output SPSS

Dari hasil uji anova atau $\mathrm{F}$ test menunjukkan bahwa $\mathrm{F}$ hitung adalah 64,630 dengan tingkat signifikansi 0,00. Karena probabilitas 0,00 lebih kecil dari 0,05 maka model regresi tersebut signifikan.

Oleh karena itu untuk tahun periode 2012-2016 keseluruhan hipotesis menyatakan bahwa variabel independen disini adalah penjualan memiliki pengaruh yang signifikan terhadap likuiditas.

\section{b. Koefisien Regresi}

TABEL 4.10

\section{Coefficients $^{\mathrm{a}}$}

\begin{tabular}{|cc|l|l|l|l|l|}
\hline \multirow{2}{*}{ Model } & \multicolumn{2}{|l|}{$\begin{array}{l}\text { Unstandardized } \\
\text { Coefficients }\end{array}$} & $\begin{array}{l}\text { Standardized } \\
\text { Coefficients }\end{array}$ & T & \multirow{2}{*}{ Sig. } \\
\cline { 3 - 5 } & B & Std. Error & Beta & & \\
\hline \multirow{2}{*}{1} & (Constant) & .435 & .192 & & 2.262 & .027 \\
& Penjualan & .909 & .113 & .726 & 8.039 & .000 \\
\hline
\end{tabular}

a. Dependent Variable: Current

Sumber Output SPSS

Persamaan koefisien regresi sederhana dengan 1 variabel independen (Bebas) yaitu likuiditas sebagai berikut :

$\mathrm{Y}=\mathrm{b} 0-\mathrm{bX}$

$\mathrm{Y}=0,435-0,909$

1. Konstanta $\mathrm{b} 0=0,435$

Artinya jika jumlah Penjualan nilainya adalah 0 , maka nilai likuiditas sebesar 0,435

2. Koefisien $b=0,909$

Artinya jika penjualan meningkat Rp. 1,- maka akan meningkatkan likuiditas sebesar 0,909

Uji T Statistik

TABEL 4.11

\section{Coefficients $^{\mathrm{a}}$}

\begin{tabular}{|c|c|c|c|c|c|}
\hline \multirow[t]{2}{*}{ Model } & \multicolumn{2}{|c|}{$\begin{array}{l}\text { Unstandardized } \\
\text { Coefficients } \\
\end{array}$} & $\begin{array}{l}\text { Standardized } \\
\text { Coefficients }\end{array}$ & \multirow[t]{2}{*}{$\mathrm{T}$} & \multirow[t]{2}{*}{ Sig. } \\
\hline & B & Std. Error & Beta & & \\
\hline $\begin{array}{l}\text { (Constant) } \\
\text { Penjualan }\end{array}$ & $\begin{array}{l}.435 \\
.909\end{array}$ & $\begin{array}{l}.192 \\
.113\end{array}$ & .726 & $\begin{array}{l}2.262 \\
8.039\end{array}$ & $\begin{array}{l}.027 \\
.000\end{array}$ \\
\hline
\end{tabular}

a. Dependent Variable: Current

Sumber Output SPSS

Uji statistic $t$ menunjukkan seberapa jauh pengaruh satu variabel independen secara individual dalam menerangkan variasi variabel dependen. Apakah variabel independen berpengaruh atau tidak.

Hipotesis :

Ho $=$ koefisien regresi tidak signifikan

$\mathrm{H}_{1}=$ koefisien regresi signifikan

Pengambilan keputusan berdasarkan probabilitas :

- Jika probabilitas $>0.05$, maka Ho diterima

- Jika probabilitas <0,05, maka Ho ditolak 
Berdasarkan tabel diatas dapat dijelaskan pengujian hipotesis dengan uji t sebagai berikut :

Pengujian Hipotesis

$\mathrm{H}_{0}: \mathrm{b}_{1}=0$ Artinya tidak terdapat pengaruh Penjualan terhadap Likuiditas.

$\mathrm{H}_{0}: \mathrm{b}_{1} \neq 0$ Artinya terdapat pengaruh signifikan antara Penjualan terhadap Likuiditas.

Uji t menunjukkan nilai signifikan sebesar $0.00<0.05$ hal ini dapat diartikan bahwa variabel penjualan berpengaruh secara signifikan terhadap Likuiditas.

\section{c. Hipotesis}

Berdasarkan program SPSS 21 yang terdapat dalam tabel coefficients diperoleh nilai $t$ hitung sebesar 8.039 kemudian t hitung ini dibandingkan dengan t tabel dengan level of significence adalah 0,05 diperoleh nilai t tabel sebesar 3,182. Ternyata t hitung lebih kecil daripada tabel $(8.039>3,182)$ atau dengan melihat kolom sig diperoleh lebih dari 0,05 , nilai tersebut lebih dari nilai $\alpha=0,05$. Dengan demikian, H0 ditolak dan H1 diterima. Dengan ditolaknya H0 bahwa penjualan berpengaruh signifikan terhadap likuiditas.

\section{Quick Ratio}

\section{Analisa Regresi linear sederhana atau Koefisien determinasi}

\section{TABEL 4.12}

\begin{tabular}{|l|l|l|l|l|}
\hline Model & R & R Square & $\begin{array}{l}\text { Adjusted Rodel Summary } \\
\text { Square }\end{array}$ & $\begin{array}{l}\text { Std. Error of the } \\
\text { Estimate }\end{array}$ \\
\hline 1 & $.689^{\mathrm{a}}$ & .474 & .465 & .2472725154 \\
\hline
\end{tabular}

a. Predictors: (Constant), Penjualan

Sumber output SPSS

Dari tabel Model Summary diatas menunjukkan Angka R hitung sebesar 0,689 menunjukkan bahwa korelasi atau hubungan antara penjualan terhadap Likuditas kuat karena memiliki angka di antara 0,60-0,799.

Angka R Square $\left(\mathrm{R}^{2}\right)$ atau koefisien determinasi adalah 0.474 berasal dari $0.689 \mathrm{x}$ 0.689 . Hal ini $R$ square penjualan memiliki kontribusi terhadap likuiditas sebesar $47,4 \%$ sementara $52,6 \%$ di pengaruhi oleh faktor-faktor lain.

\section{Uji F Statistik}

ANOVA $^{\mathrm{a}}$

TABEL 4.13

\begin{tabular}{|ll|l|l|l|l|l|}
\hline \multicolumn{2}{|l|}{ Model } & $\begin{array}{l}\text { Sum of } \\
\text { Squares }\end{array}$ & df & Mean Square & F & Sig. \\
\hline \multirow{2}{*}{1} & Regression & 3.199 & 1 & 3.199 & 52.321 & $.000^{\mathrm{b}}$ \\
& Residual & 3.546 & 58 & .061 & & \\
& Total & 6.745 & 59 & & & \\
\hline
\end{tabular}

a. Dependent Variable: Quick

b. Predictors: (Constant), Penjualan

Sumber output SPSS

Dari hasil uji anova atau $\mathrm{F}$ test menunjukkan bahwa $\mathrm{F}$ hitung adalah 52,321 dengan tingkat signifikansi 0,00. Karena probabilitas 0,00 lebih kecil dari 0,05 maka model regresi signifikan.

Oleh karena itu untuk tahun periode 2012-2016 keseluruhan hipotesis menyatakan bahwa variabel independen disini adalah penjualan memiliki pengaruh yang signifikan terhadap Likuditas. 


\section{Koefisien Regresi}

TABEL 4.14

Coefficients $^{\mathbf{a}}$

\begin{tabular}{|ll|l|l|l|l|l|}
\hline \multicolumn{2}{|l|}{ Model } & \multicolumn{2}{|l|}{$\begin{array}{l}\text { Unstandardized } \\
\text { Coefficients }\end{array}$} & $\begin{array}{l}\text { Standardized } \\
\text { Coefficients }\end{array}$ & $\mathrm{t}$ & \multirow{2}{*}{ Sig. } \\
\cline { 3 - 5 } & $\mathrm{B}$ & Std. Error & Beta & & \\
\hline \multirow{2}{*}{1} & (Constant) & .111 & .159 & & .699 & .487 \\
& Penjualan & .674 & .093 & .689 & 7.233 & .000 \\
\hline
\end{tabular}

a. Dependent Variable: Quick

Sumber output SPSS

Persamaan koefisien regresi sederhana dengan 1 variabel independen (Bebas) yaitu Quick Ratio sebagai berikut :

$\mathrm{Y}=\mathrm{b} 0-\mathrm{bX}$

$\mathrm{Y}=0,111-0,674$

1 .

Konstanta $\mathrm{b} 0=0,111$

Artinya jika jumlah penjualan nilainya adalah 0 , maka nilai likuiditas sebesar 0,111.

2. Koefisien $b=0,674$

Artinya jika penjualan meningkat Rp 1,- maka akan menaikan likuiditas sebesar 0,674.

Uji T Statistik

TABEL 4.15

\section{Coefficients $^{\mathrm{a}}$}

\begin{tabular}{|ll|l|l|l|l|l|}
\hline \multicolumn{2}{|l|}{ Model } & \multicolumn{2}{|l|}{$\begin{array}{l}\text { Unstandardized } \\
\text { Coefficients }\end{array}$} & $\begin{array}{l}\text { Standardized } \\
\text { Coefficients }\end{array}$ & & \multirow{2}{*}{ Sig. } \\
\cline { 3 - 5 } & & $\mathrm{B}$ & Std. Error & Beta & & \\
\hline \multirow{2}{*}{1} & (Constant) & .111 & .159 & & .699 & .487 \\
& Penjualan & .674 & .093 & .689 & 7.233 & .000 \\
\hline
\end{tabular}

a. Dependent Variable: Quick

Sumber output SPSS

Uji statistik $\mathrm{t}$ menunjukkan seberapa jauh pengaruh satu variabel independen secara individual dalam menerangkan variasi variabel dependen. Apakah variabel independen berpengaruh atau tidak.

Hipotesis :

Ho $=$ koefisien regresi tidak signifikan

$\mathrm{H} 1$ = koefisien regresi signifikan

Pengambilan keputusan berdasarkan probabilitas :

Jika probabilitas $>0.05$, maka Ho diterima

Jika probabilitas $<0,05$, maka Ho ditolak

Berdasarkan tabel diatas dapat dijelaskan pengujian hipotesis dengan uji t sebagai berikut :

Pengujian Hipotesis

$\mathrm{H} 0: \mathrm{b} 1=0$ Artinya tidak terdapat pengaruh penjualan terhadap likuditas.

$\mathrm{H} 0: \mathrm{b} 1 \neq 0$ Artinya terdapat pengaruh signifikan antara penjualan terhadap likuiditas.

Uji t menunjukkan nilai signifikan sebesar $0.00<0.05$ hal ini dapat diartikan bahwa variabel penjualan berpengaruh secara signifikan terhadap likuiditas.

\section{Hipotesis}

Berdasarkan program SPSS 21 yang terdapat dalam tabel coefficients diperoleh nilai t hitung sebesar 7,233 kemudian thitung ini dibandingkan dengan $t$ tabel dengan level of significence 
adalah 0,05 diperoleh nilai $\mathrm{t}$ tabel sebesar 3,182. Ternyata $\mathrm{t}$ hitung lebih besar daripada t tabel $(7,233>3,182)$ atau dengan melihat kolom sig diperoleh kurang dari 0,05 , nilai tersebut kurang dari nilai $\alpha=0,05$. Dengan demikian, H0 ditolak dan H1 diterima. Dengan diterimanya H1 bahwa penjualan berpengaruh signifikan terhadap likuiditas.

\section{Cash Ratio}

\section{Analisa Regresi linear sederhana atau Koefisien determinasi}

TABEL 4.16

\section{Model Summary}

\begin{tabular}{|l|l|l|l|l|}
\hline Model & $\mathrm{R}$ & R Square & $\begin{array}{l}\text { Adjusted R } \\
\text { Square }\end{array}$ & $\begin{array}{l}\text { Std. Error of the } \\
\text { Estimate }\end{array}$ \\
\hline 1 & $.807^{\mathrm{a}}$ & .651 & .645 & .0343901957 \\
\hline
\end{tabular}

a. Predictors: (Constant), Penjualan

Sumber output SPSS

Dari tabel Model Summary diatas menunjukkan Angka R hitung sebesar 0,807 menunjukkan bahwa korelasi atau hubungan antara penjualan terhadap likuditas kuat karena memiliki angka antara 0,60-0,799.

Angka R Square $\left(\mathrm{R}^{2}\right)$ atau koefisien determinasi adalah 0,651 berasal dari $0,807 \mathrm{x}$ 0,807 . Hal ini $\mathbf{R}$ square penjualan memiliki kontribusi terhadap likuiditas sebesar $65,1 \%$ sementara $34,9 \%$ di pengaruhi oleh faktor-faktor lain.

Uji F Statistik

TABEL 4.17

ANOVA $^{\mathrm{a}}$

\begin{tabular}{|ll|ll|l|l|l|l|}
\hline \multicolumn{2}{|l|}{ Model } & $\begin{array}{l}\text { Sum } \\
\text { Squares }\end{array}$ & of & df & Mean Square & F & Sig. \\
\hline \multirow{4}{*}{1} & Regression & .128 & 1 & .128 & 108.274 & $.000^{\mathrm{b}}$ \\
& Residual & .069 & 58 & .001 & & \\
& Total & .197 & 59 & & & \\
\hline
\end{tabular}

a. Dependent Variable: Cash

b. Predictors: (Constant), Penjualan

Sumber output SPSS

Dari hasil uji anova atau F test menunjukkan bahwa F hitung adalah 108,274 dengan tingkat signifikansi 0,000. Karena probabilitas 0,00 lebih kecil dari 0,05 maka model regresi signifikan.

Oleh karena itu untuk tahun periode 2012-2016 keseluruhan hipotesis menyatakan bahwa variabel independen disini adalah penjualan memiliki pengaruh yang signifikan terhadap likuiditas.

\section{Koefisien Regresi}

\section{TABEL 4.18}

\section{Coefficients $^{\mathbf{a}}$}

\begin{tabular}{|ll|l|l|l|l|l|}
\hline \multirow{2}{*}{ Model } & \multicolumn{2}{|l|}{$\begin{array}{l}\text { Unstandardized } \\
\text { Coefficients }\end{array}$} & $\begin{array}{l}\text { Standardized } \\
\text { Coefficients }\end{array}$ & T & \multirow{2}{*}{ Sig. } \\
\cline { 3 - 5 } & $\mathrm{B}$ & Std. Error & Beta & & \\
\hline \multirow{2}{*}{1} & (Constant) & .185 & .022 & & 8.366 & .000 \\
& Penjualan & .135 & .013 & .807 & 10.405 & .000 \\
\hline
\end{tabular}

\section{a. Dependent Variable: Cash}

Sumber output SPSS 
Persamaan koefisien regresi sederhana dengan 1 variabel independen (Bebas) yaitu likuditas sebagai berikut :

$\mathrm{Y}=\mathrm{b} 0-\mathrm{bX}$

$\mathrm{Y}=0,185-0,135$

1. Konstanta $\mathrm{b} 0=0,185$

Artinya jika jumlah penjualan nilainya adalah 0 , maka nilai likuiditas sebesar 0,185 .

2. Koefisien $b=0,135$

Artinya jika penjualan meningkat Rp. 1,- maka akan meingkatkan likuditas sebesar 0,135.

Uji T Statistik

TABEL 4.19

\section{Coefficients $^{\mathrm{a}}$}

\begin{tabular}{|cc|l|l|l|l|l|}
\hline \multirow{2}{*}{ Model } & \multicolumn{2}{|l|}{$\begin{array}{l}\text { Unstandardized } \\
\text { Coefficients }\end{array}$} & $\begin{array}{l}\text { Standardized } \\
\text { Coefficients }\end{array}$ & T & \multirow{2}{*}{ Sig. } \\
\cline { 3 - 5 } & $\mathrm{B}$ & Std. Error & Beta & & \\
\hline \multirow{2}{*}{1} & (Constant) & .185 & .022 & & 8.366 & .000 \\
& Penjualan & .135 & .013 & .807 & 10.405 & .000 \\
\hline
\end{tabular}

a. Dependent Variable: Cash

Sumber output SPSS

Uji statistic t menunjukkan seberapa jauh pengaruh satu variabel independen secara individual dalam menerangkan variasi variabel dependen. Apakah variabel independen berpengaruh atau tidak.

Hipotesis :

Ho $=$ koefisien regresi tidak signifikan

$\mathrm{H} 1$ = koefisien regresi signifikan

Pengambilan keputusan berdasarkan probabilitas :

Jika probabilitas $>0.05$, maka Ho diterima

Jika probabilitas $<0,05$, maka Ho ditolak

Berdasarkan tabel diatas dapat dijelaskan pengujian hipotesis dengan uji t sebagai berikut:

Pengujian Hipotesis

$\mathrm{H} 0: \mathrm{b} 1=0$ Artinya tidak terdapat pengaruh penjualan terhadap likuiditas.

$\mathrm{H} 0: \mathrm{b} 1 \neq 0$ Artinya terdapat pengaruh signifikan antara penjualan terhadap likuiditas.

Uji t menunjukkan nilai signifikan sebesar $0.00<0.05$ hal ini dapat diartikan bahwa variabel penjualan secara berpengaruh secara signifikan terhadap likuiditas.

\section{Hipotesis}

Berdasarkan program SPSS 21 yang terdapat dalam tabel coefficients diperoleh nilai t hitung sebesar 10,405 kemudian $t$ hitung ini dibandingkan dengan $t$ tabel dengan level of significence adalah 0,05 diperoleh nilai $t$ tabel sebesar 3,182 . Ternyata $t$ hitung lebih kecil daripada t tabel $(10,405>3,182)$ atau dengan melihat kolom sig diperoleh lebih dari 0,05, nilai tersebut lebih dari nilai $\alpha=0,05$. Dengan demikian, H0 ditolak dan H1 diterima. Dengan ditolaknya H0 bahwa penjualan berpengaruh signifikan terhap likuiditas.

\section{PENUTUP}

Berdasarkan hasil pengujian analisis bahwa variabel penjualan berpengaruh secara signifikan terhadap Current Rasio. Hasil bahwa volume penjualan memiliki nilai yang sangat kuat terhadap Current Ratio. Variabel penjualan berpengaruh secara signifikan terhadap Quick Rasio. Variabel penjualan berpengaruh secara signifikan terhadap Cash Rasio. Uji hipotesis dengan menggunakan analisis korelasi diperoleh hasil bahwa volume penjualan memiliki nilai yang sangat kuat terhadap Cash Rasio. Interprestasi pada koefisien korelasi nilai tersebut memiliki pengaruh kuat, yang artiya penjualan berpengaruh kuat terhadap likuiditas. 
Berdasarkan hasil penelitian yang dilakukan pada PT. CAHAYA PRIMA SENTOSA maka penulis memberikan saran-saran sebagai berikut :

a. Agar dapat meningkatkan current ratio yaitu cara meningkatkan jumlah aktiva lancar dan mengurangi jumlah hutang lancar perusahaan, misalnya dengan menjual aktiva tetap diupayakan untuk meningkatkan aktiva lancar atau untuk menggurangi utang lancar. Menurut Sawir (2009:10) Current ratio yang rendah biasanya dianggap menunjukkan terjadinya masalah dalam likuidasi, sebaliknya current ratio yang terlalu tinggi juga kurang bagus, karena menunjukkan banyaknya dana menganggur yang pada akhirnya dapat mengurangi kemampuaan perusahaan.

b. Untuk meningkatkan quick ratio adalah dengan cara menambah aktiva lancar dan mengurangi utang lancar atau persediaan serta perusahaan harus membuat membuat perencanaan keuangan dengan baik. Menurut Kasmir (2012:136) "Rasio cepat (quick ratio) atau rasio sangat lancar atau acid test ratio merupakan rasio yang menunjukkan kemampuan perusahaan dalam memenuhi atau membayar kewajiban atau utang lancar (utang jangk pendek) dengan aktiva lancar tanpa memperhitungkan nilai sediaan (inventory)."

c. Bertambah tinggi Cash Ratio berarti jumlah uang tunai yang tersedia makin besar sehingga pelunasan utang pada saat jatuh tempo tidak akan mengalami kesulitan. Tetapi bila terlalu tinggi akan mengurangi potensi untuk mempertinggi Rate Of Return. Upaya yang harus dilakukan untuk meningkatkan cash ratio adalah menambah jumlah kas atau mengurangi hutang lancar serta perusahaan harus membuat perencanaan keuangan dengan baik.

d. Variabel dependen yang digunakan dalam penelitian ini terdiri dari Current Ratio, Quick Ratio dan Cash Ratio, maka dari itu penulis menyarankan agar kinerja keuangan tidak hanya diukur menggunakan Current Ratio, Quick Ratio dan Cash Ratio, tetapi dengan rasiorasio lainnya agar menghasilkan hasil penelitian yang lebih akurat atau signifikan.

\section{REFERENSI}

Abdullah, Thamrin dan Francis Tantr, 2016, Manajemen Pemasaran, Edisi Pertama, Cetakan Kelima, Jakarta : PT Rajagrafindo Persada.

Agus Sartono, 2010, Manajemen Keuangan Teori dan Aplikasi, Edisi Keempat, Yogyakarta : BPFE.

Bambang Riyanto, 2010, Dasar-Dasar Pembelanjaan Perusahaan, Edisi Keempat, Yogyakarta : BPFE.

Basu Swastha DH., Irawan, 2008, Manajemen Pemasaran Modern, Edisi Kedua, Cetakan Ketiga belas, Yogyakarta : Liberty Offset.

Basu Swastha, Hani Handoko, 2011, Manajemen Pemasaran-Analisis Perilaku Konsume, Yogyakarta : BPFE.

Bongsu Saragih ,2012, Pengaruh Kebijakan Penjualan Terhadap Likuiditas di perusahaan

Otomotif di BEI, Fakultas Ekonomi Universitas Krisnadwipayana.

Bustami Bastian, Nurlela, 2010, Akuntansi Biaya. Yogyakarta : Graha Ilmu

Drs. S. Munawir, 2010, Analisa Laporan Keuangan, Yogyakarta : Liberty.

Kasmir, 2012, Analisis Laporan Keuangan, PT.Raja Grafindo Persada, Jakarta.

K. R. Subramanyam \& John J. Wild, 2012, Analisis Laporan Keuangan (Edisi 10, Buku 1). Jakarta: Salemba Empat.

Mulyadi, 2010, Sistem Akuntansi, Edisi Ketiga, Cetakan Kelima, Penerbit Salemba Empat, Jakarta.

Siti Marhamah, 2015, Pengaruh Penjualan Terhadap Likuiditas PT. Bintang Kharisma Jaya, Fakultas Ekonomi STIE Muhammadiyah Jakarta.

Sugiyono, 2013, Metode Pendidikan Pendekatan Peneletian Kuantitatif, Kualitatif dan R\&D, CV. Alfabeta: Bandung.

Sulistiyowati, Leny, 2010, Panduan Praktis Memahami Analisis Laporan Keuangan, Jakarta : PT Elex Media Komputindo. 